\title{
PERAN PANTI ASUHAN ALMUHAJIRIN KOTA PALU DALAM MEMBENTUK KARAKTER RELIGIUS ANAK DITINJAU DARI HUKUM ISLAM
}

\author{
Hairuddin Cikka, Usman Hamid
}

\begin{abstract}
This research focuses on the role of Al Muhajirin Orphanage in Palu City in building religious character of children reviewed from Islamic law. This research used qualitative research method through observation, in-depth interviews, and documentation study. The data obtained were analyzed using data reduction technique, data presentation, data verification, and drawing conclusions.

The results showed that: (1). The caregivers' efforts in building the religious character of children were strongly supported by the situation and condition of Al Muhajirin Orphanage marked by the stay of foster children in the dormitory, so that religious-based character building could be performed optimally. The religious-based character values that were developed including being religious, disciplined, like to read, caring for the environment, responsible, and honest. The implementation of religious-based character formation aims to make a person as a good human being. The forms of implementation of character education are manifested by cultivating the faith, providing guidance, providing good role models, enforcing rules, providing advice, motivation, and conducting supervision (2). Islamic law review of the role of caregiver included educating, teaching, and training. Educating means transmitting and developing the values of life/personality. Teaching means transmitting and developing science and technology. While, training means developing skills in foster children based on QS. Al-Kahfi [18] 66-70. Meanwhile, character building in Islam is the same as moral education and it is also a purification of the soul and character of humans to become righteous humans based on the Quran and hadith.
\end{abstract}

\section{Keywords: Religious Character of Children}

\section{PENDAHULUAN}

Berbicara masalah Panti Asuhan sudah terbayang di benak kita, bahwa yang masuk sebagai santri asuhnya adalah anak-anak keluarga kurang mampu baik kemampuan dari segi ekonomi dan tanggung jawab negara, melalui instansi yang berwenang, adalah untuk menjamin supervisi keselamatan, kesejahteraan diri, dan perkembangan setiap anak yang ditempatkan dalam pengasuhan alternatif dan melakukan review secara teratur tentang ketepatan situasi 
pengasuhan yang disediakan. Sudah menjadi kewajiban bagi setiap warga Negara untuk berpartisipasi mengurusnya, manakala mengetahui ada fakir miskin, anak terlantar, terlebih anak yatim berdasarkan Peraturan Menteri Sosial Republik Indonesia Nomor: 30/Huk/2011 Tentang Standar Nasional Pengasuhan Anak Untuk Lembaga Kesejahteraan Sosial Anak dan Undang-Undang Nomor 23 Tahun 2002 tentang Perlindungan Anak. ${ }^{1}$

Pembinaan umat dalam kenyataan di masyarakat tidak bisa dipungkiri lagi bahwa suatu peran yang sangat besar di masyarakat dalam membina kaum yang lemah adalah dengan jalan kebersamaan. Hal ini sesuai perintah Allah SWT dalam QS. Ali Imron [3]: 104 sebagai berikut:

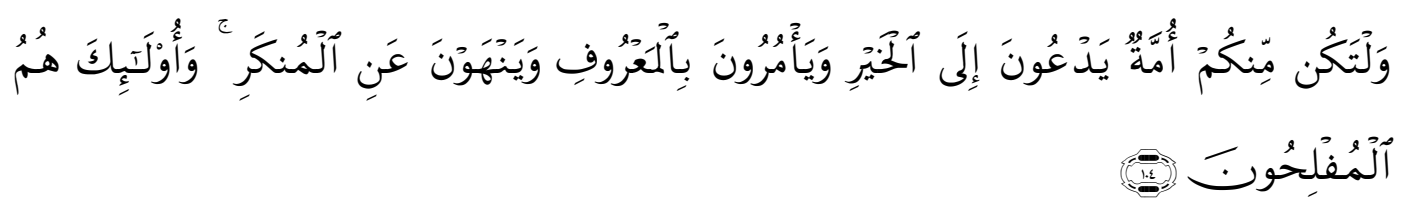

Terjemahnya:

Dan hendaklah ada diantara kamu segolongan ummat yang mengajak kepada kebajikan, menyuruh kepada yang makruf dan mencegah dari yang munkar, dan mereka itulah orang-orang yang beruntung. ${ }^{2}$

Islam memerintah untuk berdakwah dan selalu mengajak serta membawa manusia berbuat kebaikan, menyuruh berbuat ma'ruf yaitu patut, pantas dan sopan, dan mencegah perbuatan munkar yang dibenci dan tidak diterima oleh manusia. Terdapat dua kata penting yaitu menyuruh pada ma'ruf dan mencegah yang munkar. Perbuatan ma'rulf dapat dipahami oleh manusia dan patut dikerjakan oleh akal sehat. Sedangkan yang munkar ialah yang dibenci dan ditolak masyarakat, karena tidak patut, tidak selayaknya hal demikian dikerjakan oleh manusia yang berakal. Oleh sebab itu wajiblah ada dalam golongan kaum Muslimin yang berkerja keras menggerakkan orang pada yang ma'ruf dan menjahui yang munkar. ${ }^{3}$

Mengubah kaum yang lemah menjadi mampu dan menjadi sejahtera adalah suatu bentuk kebajikan, dengan demikian secara tidak langsung bisa

\footnotetext{
${ }^{1}$ A Donie Koesoema, Pendidikan Karakter, Cet. I (Jakarta: Grasindo, 2007), 102-103.

${ }^{2}$ Departemen Agama RI, Al-Qur'an dan Terjemahnya (Jakarta: Toha Putra, 2008), 124.

${ }^{3}$ Hamka, Tafsir al-Azhar, Juz 4, Cet. II. (Jakarta: Pustaka Panjimas, 2004), 37.
} 
menjauhkan kita dari kemunkaran. Sehingga didalamnya terjadi keseimbangan antara berdakwah dengan memberikan pendidikan. Keseimbangan ini dapat dicapai dengan cara melaksanakan keduanya yaitu dakwah dan pendidikan, ini sesuai dengan hak masing- masing tanpa pengurangan dan penyimpangan.

Pendidikan berguna untuk menjadikan para pembimbing, pendakwah, yang siap berkorban untuk meningkatkan derajat umat. Sedangkan dakwah berguna untuk menyelematkan orang-orang yang tenggelam dalam kesesatan, dan memberi petunjuk kepada umat agar menjadi terdidik, yang pada akhirnya bisa mengubah kenyataan yang pahit lagi menyakitkan menjadi kenyataan yang baik, terpuji dan mendapat rida Allah Swt. Telah banyak ditunjukan oleh masyarakat bahwa kebersamaan dalam membina kaum yang lemah itu diwujudkan dengan mendirikan sebuah lembaga sosial formal yaitu Panti Asuhan. Keberadaan Panti Asuhan merupakan bagian dari masyarakat, sehingga interaksi sosial akan terjadi. Warga masyarakat di sekitar Panti Asuhan merupakan sumber, baik untuk sosialisasi anak maupun dukungan-dukungan material dan finansial. Meskipun pada umumnya terbatas.

Salah satu faktor menurunnya prestasi belajar adalah pola lingkungan belajar siswa, lingkungan belajar merupakan suatu cara bagaimana siswa melaksanakan kegiatan belajar misalnya, bagaimana mereka belajar dan mengikuti pelajaran. Faktor menurunnya prestasi juga dipengaruhi oleh faktor internal dan eksternal contohnya seperti, intelegensi, minat, bakat, motivasi, gaya belajar dan pola lingkungan. Kualitas cara belajar akan menentukan kualitas hasil belajar yang diperoleh. Cara belajar yang baik akan menyebabkan berhasilnya belajar, sebaliknya cara belajar yang buruk akan menyebabkan kurang berhasil atau gagalnya belajar. ${ }^{4}$

Keutuhan keluarga merupakan sesuatu yang sangat penting dan di perlukan dalam pengasuhan anak, guna mengajarkan norma-norma atau aturanaturan dan nilai- nilai dalam masyarakat serta memberikan pembinaan agar anak menjadi pribadi yang baik. Masa anak-anak adalah masa umur keemasan karena 
76 | MUSA WA, Vol. 12 No.1 Juni $2020: 73-107$

memiliki potensi yang luar biasa untuk menjadi manusia terhormat atau menjadi manusia terhina. Anak berhak untuk tumbuh kembang secara wajar serta memperoleh perawatan, pelayanan, asuhan dan pembinaan agar mereka menjadi manusia yang berkepribadian, berbudi pekerti dan berakhlak luhur. Karena pada masa anak- anak merupakan waktu yang tepat untuk pembentukan karakter. ${ }^{5}$

Berdasarkan fitrahnya, anak merupakan makhluk ciptaan Tuhan dalam tugasnya sebagai makhluk individu dan sosial. Sebagai makhluk individu anak memilki keberagaman karakteristk yang unik pada dirinya, dimana anak memiliki kebebasan untuk berbuat dan bertingkah laku sesuai dengan potensi dan kemauannya sebagai makhluk sosial, sehingga dalam proses perjalanan anak dalam mengoptimalkan potensinya sebagai makhluk sosial perlu adanya bimbingan dan pembinaan agar nantinya hasil yang dicapai adalah hasil yang terbaik Anak merupakan faktor yang sangat penting dalam pembangunan bangsa, karena anak adalah generasi penerus perjuangan yang akan menghadapi tantangan masa depan dalam arti bahwa suatu bangsa menginginkan kemajuan, masyarakat yang sehat, religius, beriman, bertaqwa, memiliki kesadaran hukum dan lingkungan, sehingga setiap anak berhak atas perlindungan dan pengasuhan agar memiliki etos kerja yang tingi serta disiplin. ${ }^{6}$

Pada saat ini peran orang tua dan peran respon dari lingkungan sangat di perlukan bagi anak sebagai penguat untuk setiap perilaku yang telah dilakukanya.

Peran orang tua dalam pendidikan anak, jelas dan tegas bahwa mereka adalah pendidik yang utama dan pertama. Orang tua merupakan faktor internal yang berasal dari faktor genesis atau bawaan. Faktor genesis maksudnya adalah faktor yang berupa bawaan sejak lahir dan merupakan pengaruh keturunan dari salah satu sifat orang tuanya. Sedangkan faktor lingkungan merupakan faktor eksternal yang berasal dari luar orang tua, faktor ini

${ }^{5}$ Budiningsih Asri, Pembelajaran Moral, Cet. I (Jakarta : Rineka Cipta, 2004), 97.

${ }^{6}$ Wardani, Pendidikan Karakter Kajian Konseptual dan Kemungkinan Implementasi Cet. I (Jakarta: Diadit Media, 2008), 156. 
merupakan hasil pengaruh dari lingkungan seseorang mulai dari lingkungan terkecilnya, yakni keluarga, teman dan tetangga. ${ }^{7}$

Bagi anak yang memiliki keluarga secara tidak utuh karena disorganisasi keluarga seperti meninggalnya salah satu atau kedua orang tua dan krisis ekonomi keluarga, proses pembinaan menjadi kurang perhatian sehingga pendidikan terabaikan. Anak yang memiliki keluarga secara tidak utuh membutuhkan perlindungan dan tempat mengadukan segala persoalan yang dihadapinya Maka salah satu cara yang dilakukan agar anak tetap dalam asuhan adalah dengan memberikan alternatif melalui instansi pemertintah atau swasta yang berwenang atau melalui organisasi masyarakat yang diberi izin. Dengan memberikan berbagai alternatif pelayanan untuk pemenuhan kebutuhan anak dan menyiapkan masa depanya sehingga menjadi masyarakat yang produktif.

Pengertian panti asuhan menurut Yahya Khan Panti yaitu:

Panti asuhan adalah sebuah wadah bagi anak-anak yang mengalami disorganisasi dan krisis ekonomi keluarga atau dhu'afa yang nantinya akan mendapatkan pengasuhan dari pengasuh untuk di bina dan mendapatkan pengasuhan baik itu fisik, mental maupun kehidupan sosialnya. $^{8}$

\section{Menurut Kadir Panti asuhan adalah}

Tempat membentuk kembali sikap dan perilaku anak yang sesuai dengan nilai-nilai dan norma yang berlaku di masyarakat. Secara umum panti asuhan atau dalam penelitian tesis ini disebut sebagai pondok yatim bertugas menggantikan kewajiban keluarga terutama dalam hal pembinaan karakter religius kepada anak asuhnya karakter religius dibentuk melalui pembinaan yang efektif. ${ }^{9}$

Panti asuhan merupakan pendidikan nonformal yang berupaya mewujudkan potensi anak asuh dengan memberikan pembinaan karakter

\footnotetext{
${ }^{7}$ Sardjan Kadir, Perencanaan Pendidikan informal, Cet. I (Jakarta: Ciputat Press, 2002), 45-47.

${ }^{8}$ Yahya Khan, Pendidikan Karakter Berbasis Potensi Diri. Mendongkrak Kualitas Pendidikan. Cet. II (Bandung: Pelangi Publishing, 2010), 79-80.

${ }^{9}$ Sardjan Kadir, Perencanaan Pendidikan informal, Cet. III (Jakarta: Ciputat Press, 2002), 45-47.
} 
religius. Karakter religius merupakan titian ilmu pengetahuan dan keterampilan yang berlandasakn pada ajaran agama. Pengetahuan tanpa landasan kepribadian yang benar akan menyesatkan, dan ketrampilan tanpa kesadaran diri akan menghancurkan. Melalui karakter religius sebagai media untuk membina dan memberi motivasi yang dibentuk dengan metode dan proses yang bermartabat. Religius sebagai salah satu nilai karakter yangg dideskripsikan sebagai sikap dan perilaku patuh dalam melaksanakan ajaran agama yang dianut, toleran, dan hidup rukun. Karakter bukan sekedar penampilan lahiriah, melainkan mengungkapkan secara implisit hal-hal yang tersembunyi. Karakter yang baik mencakup pengertian, keperdulian dan tindakan berdasarkan nilai-nilai etika, serta meliputi aspek kognitif, emosional, dan perilaku dari kehidupan moral. ${ }^{10}$

Dalam pembentukan manusia, menurut Sudewo, peran karakter tidak dapat disisihkan, bahkan sesungguhnya karakter inilah yang menempatkan baik atau tidaknya seseorang, posisi karkater bukan menjadi pendamping kompetensi, melainkan menjadi dasar, ruh, atau jiwanya. Lebih jauh tanpa karakter, peningkatan diri dari kompetensi dapat menjadi liar, berjalan tanpa rambu aturan. Menurut Kemendiknas dalam Sudewo bahwa "karakter adalah watak, tabiat, akhlak, atau kepribadian seseorang yang terbentuk dari hasil internalisasi berbgagai kebajikan (virtues) yang diyakini dan digunakan sebagai landasan untuk cara pandang berpikir, bersikap dan bertindak. ${ }^{11}$

Pembinaan karakter religius pada anak asuh tidak terlepas dengan pembinaan keagamaan atau religius, seperti melalui mengaji, shalat berjamaah, berzikir dan sebagainya. Dengan kata lain, pembinaan karakter religius dilakukan dengan memberikan layanan sesuai dengan model pembinaan yang diberikan oleh pengasuh pondok kepada anak asuh seperti pembinaan keagamaan, fisik, mental maupun sosial yang bertujuan untuk bekal di masa datang serta berguna dalam kehidupan bermasyarakat.

\footnotetext{
${ }^{10}$ Sudjana S, Pendidikan informal Wawasan Sejarah Perkembangan Karakter, Cet. I (Jakarta: Prenada Media, 2007), 219.

${ }^{11}$ Sudewo, Penddidikan Karakter, Cet. I (Bandung: Rafika Publiset, 2008), 12.
} 
Undang Undang No. 23 tahun 2002 pasal 55 dan pasal 56 tentang Perlindungan Anak dalam penjabaranya menjelaskan bahwa:

Penyelenggaraan perawatan anak dapat dilakukan melalui lembaga atau di luar lembaga yakni dalam pembinaan panti pemertintah maupun swasta, atau dalam sistem asuhan keluarga/perseorangan, yang kemudian perawatan dan pembinaannya disesuaikan dengan perkembangan usia, kemampuan anak dan lingkunganya sehingga perkembangan anak tidak terhambat. Proses pembinaan anak yatim dapat diberikan mulai dari pembinaan psikologi, sosial, dan agama. ${ }^{12}$

Panti asuhan Almuhajirin Palu menangkap realitas sosial yang terjadi di dalam masyarakat tersebut sebagai sebuah peluang untuk membantu masyarakat dengan memberikan perhatian yang lebih menyeluruh bagi pendidikan sebagaimana mestinya, yaitu membantu memberikan pembinaan baik itu fisisk, mental maupun sosial dan memberikan kesempatan menempuh pendidikan bagi anak yatim dan dhu'afa khususnya bagi mereka yang membutuhkan. Begitu juga nlai- nilai agama dan ilmu keagamaan yang diterima. Hal ini sangat dibutuhkan bagi anak asuh yang mengalami permasalahan, baik masalah dengan keluarga, teman, keterpaksaan masuk di pondok, tidak kuat dengan peraturan, tata tertib atau lain sebagainya.

Berdasarkan observasi awal Ibrahim Dg. Tallesang selaku ketua Panti asuhan Almuhajirin Palu beliau menjelaskan bahwa Panti asuhan Almuhajirin Palu mengambil alih atau mengimbangi lemahnya peran keluarga dan juga sebagai pengasuh, pembina, dan pendidik anak asuh diantaranya untuk membina karakter anak asuh agar mereka dapat mengembangkan potensi dan kemampuanya, serta menumbuhkan kesadaran agar anak asuh memiliki pribadi yang baik. Dengan upaya pembinaan karakter religius yang diberikan pengasuh kepada para anak asuh tersebut bertujuan untuk menanamkan karakter yang baik pada anak asuh. Karakter yang baik berhubungan dengan mengetahui sesuatu yang baik (knowing the good), mencintai yang baik (loving the good), dan melakukan yang baik (acting the good). Ketiga ideal ini sangat berkaitan dalam pembentukan karakter religius yang baik pada diri seseorang. Efek yang 56.

${ }^{12}$ Undang Undang No. 23 tahun 2002 tentang Perlindungan Anak pasal 55 dan pasal 
80 | MUSA WA, Vol. 12 No.1 Juni 2020 : 73-107

mengiringi dari pembinaan pengasuh yang nantinya akan dapat mengarahkan pada anak asuh melalui pembinaan akal juga agama. ${ }^{13}$

Beliau menilai bahwa pembinaan karakter religius pada anak asuh merupakan salah satu upaya yang dilakukan pengasuh Panti asuhan Almuhajirin Palu untuk mengimbangi peran keluarga dan peran lingkungan.

\section{PEMBAHASAN}

\section{A. Teori-Teori Pendidikan Karakter Menurut Ahli}

\section{Pendidikan karakter menurut Thomas Lickona}

Pendidikan karakter adalah untuk membentuk penyempurnaan diri individu secara terus-menerus dan melatih kemampuan diri demi menuju kearah hidup yang lebih baik. Menurut Lickona Karakter terbagi atas beberapa bagian yang tercakup di dalamnya yaitu sebagai berikut:

"Character so conceived has three interrelated parts: moral knowing, moral feeling, and moral behavior. Good character consists of knowing the good, desiring the good, and doing the good, habits of the mind, habits of the heart, and habits of action. All three are necessary for leading a moral life, all three make up moral maturity. When we think about the kind of character we want for our children, it's clear that we want them to be able to judge what is right, care deeply about what is right, and then do what they believe to be right, even in the face of pressure from without and temptation from within."

"Karakter yang dikandung memiliki tiga bagian yang saling terkait: pengetahuan moral, perasaan moral, dan perilaku moral. Karakter yang baik terdiri dari mengetahui yang baik, menginginkan yang baik, dan melakukan yang baik, kebiasaan pikiran, kebiasaan hati, dan kebiasaan bertindak. Ketiganya diperlukan untuk menjalani kehidupan moral, ketiganya membentuk kematangan moral. Ketika kita berpikir tentang jenis karakter yang kita inginkan untuk anak-anak kita, jelas bahwa kita ingin mereka dapat menilai apa yang benar, sangat peduli tentang apa yang benar, dan kemudian melakukan apa yang mereka yakini benar, bahkan di wajah tekanan dari luar dan godaan dari dalam."

\footnotetext{
${ }^{13}$ F.X.Supriyono Raharjo, Pembentukan Karakter dan Pengembanagan Kompetensi Siswa, Cet. I (Bandung: Tiga Serangkai, 2006), 98.

${ }^{14}$ Thomas lickona, Terjemahan; education of carakter, Bandung: alfabeta,1991.(https://www.scribd.com/07/ringkasan+buku+karakter+lickona/htm), Diakses 12 Maret 2019
} 
Berdasarkan pendapat Lickona di atas dapat dijelaskan bahwa karakter terdiri atas tiga korelasi antara lain moral knowing, moral feeling, dan moral behavior. Karakter itu sendiri terdiri atas, antara lain: mengetahui hal-hal yang baik, memiliki keinginan untuk berbuat baik, dan melaksanakan yang baik tadi berdasarkan atas pemikiran, dan perasaan apakah hal tersebut baik untuk dilakukan atau tidak, kemudian dikerjakan. Ketiga hal tersebut dapat memberikan pengarahan atau pengalaman moral hidup yang baik, dan memberikan kedewasaan dalam bersikap.

Secara sederhana, pendidikan karakter dapat didefinisikan sebagai segala usaha yang dapat dilakukan untuk mempengaruhi karakter siswa. Tetapi untuk mengetahui pengertian yang tepat, dapat dikemukakan di sini definisi pendidikan karakter yang disampaikan oleh thomas lickona. Lickona menyatakan bahwa pengertian pendidikan karakter adalah suatu usaha yang disengaja untuk membantu seseorang sehingga dapat memahami, memperhatikan, dan melakukan nilai-nilai etika yang inti.

\section{Pendidikan karakter menurut Kertajaya}

Karakter adalah ciri khas yang dimiliki oleh suatu benda atau individu. Ciri khas tersebut adalah asli dan mengakar pada kepribadian benda atau individu tersebut, serta merupakan "mesin" yang mendorong bagaimana seorang bertindak, bersikap, berucap, dan merespon sesuatu.

\section{Pengertian karakter Menurut Tadkiroatun Musfiroh}

Karakter mengacu kepada serangkaian sikap, perilaku, motivasi, dan keterampilan. Karakter berasal dari bahasa Yunani yang berarti "to mark" atau menandai dan memfokuskan bagaimana mengaplikasikan nilai kebaikan dalam bentuk tindakan atau tingkah laku, sehingga orang yang tidak jujur, kejam, rakus dan perilaku jelek lainnya dikatakan orang berkarakter jelek. Sebaliknya, orang yang perilakunya sesuai dengan kaidah moral disebut dengan berkarakter mulia. ${ }^{15}$

Karakter mulia berarti individu memiliki pengetahuan tentang potensi dirinya, yang ditandai dengan nilai-nilai seperti reflektif, percaya diri, rasional,

\footnotetext{
${ }^{15}$ Tadkirotun Musfidah, Pembinaan karakter di SM, Cet. III (Jakarta: Direktorat PSMP,
} 2008), 128 
82 | MUSA WA, Vol. 12 No.1 Juni $2020: 73-107$

logis, kritis, analitis, kreatif dan inovatif, mandiri, hidup sehat, bertanggung jawab, cinta ilmu, sabar, berhati-hati, rela berkorban, pemberani, dapat dipercaya, jujur, menepati janji, adil, rendah hati, malu berbuat salah, pemaaf, berhati lembut, setia, bekerja keras, tekun, ulet/gigih, teliti, berinisiatif, berpikir positif, disiplin, antisipatif, inisiatif, visioner, bersahaja, bersemangat, dinamis, hemat/efisien, menghargai waktu, pengabdian/dedikatif, pengendalian diri, produktif, ramah, cinta keindahan (estetis), sportif, tabah, terbuka, tertib. Individu juga memiliki kesadaran untuk berbuat yang terbaik atau unggul, dan individu juga mampu bertindak sesuai potensi dan kesadarannya tersebut. Karakteristik adalah realisasi perkembangan positif sebagai individu (intelektual, emosional, sosial, etika, dan perilaku).

Individu yang berkarakter baik atau unggul adalah seseorang yang berusaha melakukan hal-hal yang terbaik terhadap Allah Swt, dirinya, sesama, lingkungan, bangsa dan negara serta dunia internasional pada umumnya dengan mengoptimalkan potensi (pengetahuan) dirinya dan disertai dengan kesadaran, emosi dan motivasinya (perasaannya).

Pendidikan karakter adalah suatu sistem penanaman nilai-nilai karakter kepada warga sekolah yang meliputi komponen pengetahuan, kesadaran atau kemauan, dan tindakan untuk melaksanakan nilai-nilai tersebut. Pendidikan karakter dapat dimaknai sebagai "the deliberate use of all dimensions of school life to foster optimal character development". Dalam pendidikan karakter di sekolah, semua komponen (pemangku pendidikan) harus dilibatkan, termasuk komponen-komponen pendidikan itu sendiri, yaitu isi kurikulum, proses pembelajaran dan penilaian, penanganan atau pengelolaan mata pelajaran, pengelolaan sekolah, pelaksanaan aktivitas atau kegiatan kokurikuler, pemberdayaan sarana prasarana, pembiayaan, dan ethos kerja seluruh warga sekolah/lingkungan. Di samping itu, pendidikan karakter dimaknai sebagai suatu perilaku warga sekolah yang dalam menyelenggarakan pendidikan harus berkarakter. $^{16}$

\footnotetext{
${ }^{16}$ Ibid.,
} 
Berdasarkan beberapa teori pengertian pendidikan karakter yang telah dipaparkan maka penulis menyimpulkan bahwa Pendidikan karakter adalah suatu sistem penanaman nilai-nilai karakter kepada warga sekolah yang meliputi komponen pengetahuan, kesadaran atau kemauan, dan tindakan untuk melaksanakan nilai-nilai tersebut. Pendidikan karakter dapat dimaknai sebagai "Penggunaan semua dimensi kehidupan sekolah yang disengaja untuk mendorong pengembangan karakter yang optimal". Dalam pendidikan karakter di sekolah, semua komponen (pemangku pendidikan) harus dilibatkan, termasuk komponenkomponen pendidikan itu sendiri, yaitu isi kurikulum, proses pembelajaran dan penilaian, penanganan atau pengelolaan mata pelajaran, pengelolaan sekolah, pelaksanaan aktivitas atau kegiatan kokurikuler, pemberdayaan sarana prasarana, pembiayaan, dan ethos kerja seluruh warga sekolah/lingkungan.

\section{B. Pendidikan Akhlak (karakter) Anak Menurut Imam Al-Ghazali}

\section{Pendidikan Akhlak bagi Anak-anak (Anak Didik)}

Masa pendidikan di sekolah dasar, merupakan kesempatan pertama yang sangat baik untuk membina pribadi anak setelah orang tua. Seandainya guru-guru (baik guru umum, maupun guru agama) di sekolah dasar itu memiliki persyaratan kepribadian dan kemampuan untuk membina pribadi anak, maka anak yang tadinya sudah mulai bertumbuh kearah yang kurang baik dapat segera diperbaiki. Dan anak yang dari semula telah mepunyai dasar yang baik dari rumah dapat dilanjutkan pembinaannya dengan cara yang lebih sempurna lagi. ${ }^{17}$

Imam Al-Ghazali sangat menganjurkan agar mendidik anak dan membina akhlaknya dengan cara latihan-latihan dan pembiasaan-pembiasaan yang sesuai dengan perkembangan jiwanya walaupun seakan-akan dipaksakan, agar anak dapat terhindar dari keterlanjuran yang menyesatkan. Oleh karena latihan dan pembiasaan tersebut akan membentuk sikap tertentu pada anak, yang lambat laun sikap itu akan bertambah jelas dan kuat dan akhirnya tidak tergoyahkan lagi karena telah masuk menjadi bagian dari kepribadiannya. ${ }^{18}$

\footnotetext{
${ }^{17}$ Zakiah Daradjat, Ilmu Jiwa Agama, Cet. XXII (Jakarta: Bulan Bintang, 2003), 68.

${ }^{18}$ Ibid, 107.
} 
84 | MUSA WA, Vol. 12 No.1 Juni $2020: 73-107$

Konsepsi pendidikan modern saat ini sejalan dengan pandangan Imam AlGhazali tentang pentingnya pembiasaan melakukan suatu perbuatan sebagai suatu metoda pembentukan akhlak yang utama, terutama karena pembiasaan itu dapat berpengaruh baik terhadap jiwa manusia, yang memberikan rasa nikmat jika diamalkan sesuai dengan akhlak yang telah terbentuk dalam dirinya. ${ }^{19}$ Begitu pula metode mendidik anak/murid pada masa kini yang menetapkan bahwa dengan cara mengulang-ulangi pengalaman dalam berbuat sesuatu dapat meninggalkan kesan-kesan yang baik dalam jiwanya, dan dari aspek inilah anak akan medapatkan kenikmatan pada waktu mengulang-ulangi pengalaman yang baik itu, berbeda dengan pengalaman yang diperoleh dengan tanpa melalui praktik, maka kesan-kesan yang ditinggalkan adalah jelek.

Berdasarkan uraian di atas jelaslah bahwa Imam Al-Ghazali memandang pentingnya pendidikan akhlak dan kesopanan bagi anak, yang mengandung kekawanan dalam kehidupan anak, dan jika anak ditinggalkan tanpa dididik akhlaknya, maka ia akan tumbuh kearah kehidupan yang penuh siksaan atau penderitaan. $^{20}$

\section{Metode Mendidik Akhlak Anak-anak}

Menurut sejarah pendidikan Islam dapat diketahui bahwa para pendidik muslim dalam berbagai situasi dan kondisi yang berbeda, telah menerapkan berbagai metode pendidikan atau pengajaran. ${ }^{21}$ Karena metode pendidikan Islam sangat efektif dalam membina akhlak anak didik, bahkan tidak sekedar itu metode pendidikan Islam memberikan motivasi sehingga memungkinkan umat Islam mampu menerima petunjuk dari Allah. ${ }^{22}$ Metode-metode yang dipergunakan tidak hanya metode mendidik/mengajar dari para pendidik, melainkan juga metode belajar yang harus dipergunakan anak didik.

Imam Al-Ghazali seorang dari ahli fikir dan ahli tasawuf Islam yang terkenal dengan gelar "Pembela Islam" (Hujjatul Islam) banyak mencurahkan

\footnotetext{
${ }^{19}$ Thoyib Sah Syaputra, Aqidah Akhlak Madrasah Tsanawiah Kelas Satu, Cet. I (Semarang : Toha Putra, 1994), 46-57.

${ }^{20}$ Ibid., 153.

${ }^{21}$ Arifin, Filsafat Pendidikan Islam, Cet. V (Jakarta: Bumi Aksara, 2000), 101.

${ }^{22} \mathrm{http}: / /$ riwayat.wordpress.com/2008/01/25/metode-mendidik-akhlak-anak/, Diakses 7 Agustus 2019.
} 
perhatian kepada masalah pendidikan. Menurut Imam Al-Ghazali seorang pendidik agar memperoleh sukses dalam tugasnya harus menggunakan pengaruhnya serta cara yang tepat arah. Bila dipandang dari segi filosofis, Imam Al-Ghazali adalah berfaham idealisme yang konsekuen terhadap agama.

Mengenai masalah pendidikan Imam Al-Ghazali berfaham empirisme oleh karena beliau sangat menekankan pengaruh pendidik terhadap anak didik. Misalnya didalam kitabnnya "Ihya' ulum ad-Din” juz III, Imam Al-Ghazali menguraikan antara lain: metode untuk melatih anak adalah salah satu dari halhal yang amat penting. Anak adalah amanat yang dipercayakan kepada orang tuanya. Hatinya bersih, murni laksana permata yang amat berharga, sederhana dan bersih dari ukiran atau gambaran apapun. Ia dapat menerima setiap ukiran yang digoreskan kepadanya dan ia akan cenderung kearah manapun yang kita kehendaki (condongkan). Oleh karena itu bila ia dibiasakan dengan sifat-sifat yang baik, maka akan berkembanglah sifat-sifat yang baik itu pada dirinya dan akan memperoleh kebahagiaan hidup di dunia dan akhirat. Sebaliknya bila anak tersebut kita biasakan dengan sifat-sifat yang jelek, dan kita biarkan begitu saja maka ia akan celaka dan binasa. ${ }^{23}$

Menurut Imam Al-Ghazali, metode mendidik akhlak anak dapat dilakukan dengan beberapa metode yaitu:

a. Metode cerita (hikayat)

Metode cerita merupakan jalan yang baik untuk pendidikan akhlak bagi anak-anak. Anak-anak suka mendengar cerita dan menceritakannya kembali. Keadaan ini perlu dimanfaatkan untuk meningkatkan kegairahan belajar bagi anak-anak. ${ }^{24}$ Metode mendidik akhlak melalui cerita akan memberi kesempatan bagi anak untuk berfikir, merasakan, merenungi kisah tersebut, sehingga seolah ia ikut berperan dalam kisah tersebut. Adanya keterkaitan emosi anak terhadap kisah

\footnotetext{
${ }^{23}$ Arifin, Filsafat, 101-102.

${ }^{24}$ Muhammad abdul Qadir Ahmad, Metodologi Pengajara Pendidikan Agama Islam, Cet. I (Jakarta: Direktorat Jendral Pembinaan Kelembagaan Agama Islam, 1985), 196.
} 
86 | MUSA WA, Vol. 12 No.1 Juni $2020: 73-107$

akan memberi peluang bagi anak untuk meniru tokoh-tokoh berakhlak baik, dan berusaha meninggalkan perilaku tokoh-tokoh berakhlak buruk. ${ }^{25}$

Dengan menceritakan orang-orang yang berakhlak mulia dan berbudi tinggi, maka anak-anak akan meniru dan mencontoh dari cerita-cerita tersebut. Cerita yang diceritakan kepada anak-anak adalah cerita tentang orang-orang yang jujur, lurus, rajin belajar, dan bekerja sehingga akhirnya mereka menjadi orangorang besar. ${ }^{26}$

Cerita mempunyai kekuatan dan daya tarik tersendiri dalam menarik simpati anak, perasaannya aktif, hal ini memberi gambaran bahwa cerita disenangi orang, cerita dalam Al-Quran bukan hanya sekedar memberi hiburan, tetapi untuk direnungi, karena cerita dalam Al-Quran memberi pengajaran kepada manusia. Dapat dipahami bahwa cerita dapat melunakkan hati dan jiwa anak didik, cerita tidak hanya sekedar menghibur tetapi dapat juga menjadi nasehat, memberi pengaruh terhadap akhlak dan perilaku anak, dan terakhir kisah/ cerita merupakan sarana ampuh dalam pendidikan, terutama dalam pembentukan akhlak anak.

\section{b. Metode keteladanan}

Metode keteladanan merupakan metode yang paling unggul dan paling jitu apabila dibandingkan dengan metode-metode lainnya. Melalui metode keteladanan ini, para pendidik memberi contoh atau tauladan kepada anak didiknya bagaimana cara berbicara, berbuat, bersikap, mengerjakan sesuatu atau cara beribadah, dan sebagainya. Melalui metode ini, maka anak atau peserta didik dapat melihat, menyaksikan dan meyakini cara yang sebenarnya sehingga mereka dapat melaksanakannya dengan lebih baik dan lebih mudah. ${ }^{27}$

Keteladanan yang baik sangat penting dalam pembinaan akhlak. Dengan kecenderungan senang menirunya, anak mudah mereduplikasi apa saja yang dilihatnya, bukan hanya yang baik, melainkan juga yang jelek. Sehubungan

\footnotetext{
${ }^{25}$ http://riwayat.wordpress.com/2008/01/25/metode-mendidik-akhlak-anak/, Diakses 7 Agustus 2019.

${ }^{26}$ Mahmud Yunus, Metodik Khusus Pendidikan Agama, Cet. I (Jakarta: Hidakarya Agung, 1983), 33-34. 19.

${ }^{27}$ Heri Jauhari Muchtar, Fikih Pendidikan, Cet. I (Bandung, Remaja Rosdakarya, 2005),
} 
dengan ini, pendidik harus memanfaatkan peluang, baik dengan penampilan pribadinya maupun dengan mengkondisikan lingkungan sekitar anak. ${ }^{28}$

c. Metode pembiasaan

Metode pembiasaan diri ini mendorong dan memberikan ruang kepada anak didik pada teori-teori yang membutuhkan aplikasi langsung, sehingga teori yang berat dapat menjadi ringan bagi anak didik bila sering kali dilaksanakan. ${ }^{29}$

Sehubungan dengan itu tepatlah pesan Rasulullah kepada kita agar melatih/membiasakan anak untuk melaksanakan shalat ketika mereka berusia tujuh tahun dan memukulnya (tanpa cedera/bekas) ketika mereka berumur sepuluh tahun atau lebih apabila mereka tidak mengerjakannya. Dalam metode ini diperlukan kesabaran, pengertian, dan ketelatenan orang tua, pendidik dan da'i terhadap anak atau peserta didiknya. ${ }^{30}$

Imam Al-Ghazali mengatakan bahwa semua etika keagamaan tidak mungkin akan meresap dalam jiwa sebelum jiwa itu sendiri dibiasakan dengan kebiasaan baik dan dijauhkan dari kebiasaan yang buruk. Nilai-nilai moral dan etika keagamaan haruslah mendarah daging menjadi perilaku (behaviour) dan kebiasaan (habitus) bahkan kesadaran (consciousness). ${ }^{31}$

d. Metode nasihat

Metode nasihat ini merupakan metode yang paling sering digunakan oleh para orang tua, pendidik, dan da'i terhadap anak/peserta didiknya dalam proses pendidikannya. Memberi nasihat sebenarnya merupakan kewajiban kita selaku muslim seperti tertera antara lain dalam Q.S Al Ashr [103]: 3 yaitu agar kita senantiasa memberi nasihat dalam hal kebenaran dan kesabaran. Supaya nasihat dapat terlaksana dengan baik, maka dalam pelaksanaannya perlu memperhatikan beberapa hal, yaitu:

a) Gunkan kata dan bahasa yang baik dan sopan serta mudah difahami

b) Jangan sampai menyinggung perasaan orang yang dinasihati atau orang yang ada disekitarnya

${ }^{28}$ http://bukhariumar.stainbatusangkar.ac.id/?p=20, Diakses 7 Agustus 2019.

${ }^{29}$ M. Iksan Kahar, Pendidikan Karakter pada Anak Usia Dini dalam Perspektif Islam, Musawa: Journal For Gender Studies, Vol 11(01) 2019, h. 144.

${ }^{30}$ Sahilun A. Nasir, Tinjauan Akhlak, Cet. I (Surabaya: Al-Ikhlas, 1991), 20

${ }^{31}$ (facebook.com/topic.php?uid=122204804480235\&topic=157)http://id-id, Diakses 7 Agustus 2019. 
88 | MUSA WA, Vol. 12 No.1 Juni 2020 : 73-107

c) Sesuaikan perkataan kita dengan umur, sifat dan tingkat kemampuan/kedudukan anak atau orang yang kita nasihati

d) Perhatikan saat yang tepat kita memberi nasihat. Usahakan jangan menasihati ketika kita atau yang dinasihati sedang marah

e) Perhatikan keadaan sekitar kita memberi nasihat. Usahakan jangan di hadapan orang lain atau apalagi dihadapan orang banyak (kecuali ketika memberikan ceramah/tausiyah)

f) Beri penjelasan, sebab atau kegunaan mengapa kita perlu memberi nasihat

g) Agar lebih menyentuh perasaan dan hati nuranunya, sertakan ayat-ayat AlQur'an, hadis Rasulullah atau kisah para Nabi/Rasul, para sahabatnya atau orang-orang shalih. ${ }^{32}$

e. Metode ganjaran dan hukuman

Metode ini sebenarnya berhubungan dengan pujian dan penghargaan. Imbalan atau tanggapan terhadap orang lain itu terdiri dari dua, yaitu penghargaan (reward/targhib) dan hukuman (punishment/tarhib), hukuman dapat diambil sebagai metode pendidikan apabila terpaksa atau tidak ada alternatif lain yang bisa diambil. Agama Islam memberikan arahan dalam memberikan hukuman terhadap anak/peserta didik hendaknya memperhatikan hal-hal sebagai berikut:

a. Jangan menghukum ketika marah. Karena pemberian hukuman ketika marah akan lebih bersifat emosional yang dipengaruhi nafsu syaitaniyah

b. Jangan smapai menyakiti perasaan dan harga diri anak atau orang yang kita hukum

c. Jangan sampai merendahkan derajat dan martabat orang yang bersangkutan, misalnya dengan menghina atau mencaci di depan orang lain

d. Jangan menyakiti secara fisik, misalnya menampar mukanya atau menarik kerah bajunya

e. Bertujuan mengubah perilakunya yang kurang/tidak baik. Kita menghukum karena anak/peserta didik berperilaku tidak baik. ${ }^{33}$

Metode ganjaran dan hukuman merupakan metode yang paling akhir dipergunakan dalam menyampaikan pendidikan akhlak, karena adanya ganjaran dan hukuman merupakan akibat dari adanya sebab baik, sedang hukuman adalah akibat dari adanya sebab buruk. Imam Al-Ghazali mengatakan: "tidak setuju dengan cepat-cepat menghukum seorang anak yang salah, melainkan berilah kesempatan untuk memperbaiki sendiri kesalahannya, sehingga ia menghormati

\footnotetext{
${ }^{32}$ Barmawie Umary, Materi Akhlak, Cet. I (Solo: CV. Ramadhani, 1991), 18.

${ }^{33}$ Ibid., 21-22
} 
dirinya dan merasakan akibat perbuatannya. Sanjung dan pujilah pula bila ia melakukan perbuatan-perbuatan yang terpuji yang harus mendapat ganjaran pujian dan dorongan"

1) Cara Mengajar Akhlak Kepada Anak-anak

Cara mengajarkan akhlak anak dapat dilakukan dengan taqdim al-takhalai an al-akhlaq al-mazmumah suma al-tahalli bi al-akhlaq al-mahmudah yakni dalam membawakan ajaran moral atau al-akhlaq al-mahmudah adalah dengan jalan takhalli (mengsongkan atau meninggalkan) al-akhlaq al-mazmumah (akhlak yang tercela), kemudian tahalli (mengisi atau melaksanakan) al-akhlaq almahmudah (akhlak yang terpuji). Akhlak yang tercela antara lain hasad, mengambil harta orang lain, bahil, makan riba, makan harta anak yatim. Al-akhlaq al-mazmumah yang lain adalah hianat, tidak menyampaikan amanat, su'uzan. Dalam membawakan ajaran moral itu dapat dilakukan juga dengan memberikan nasihat dan berdoa: bismillah al-rahman al-rahim alhamdu lillahi al-lazi hadana ila makarim al-akhlaq. Dalam pengajaran akhlak itu haruslah menjadikan iman sebagai fondasi dan sumbernya. Iman itu sebagai nikmat besar yang menjadikan manusia bisa meraih kebahagiaan di dunia dan akhirat. ${ }^{34}$

Adapun cara mensyukurinya adalah dengan melaksanakan amal salih (alakhlaq al-mahmudah) dan meninggalkan maksiat. Landasan pokok dari akhlak Islam ada imam, yaitu iman kepada Allah, sehingga memiliki moral force (kekuatan moral) yang sangat kuat. Iman inilah yang merupakan batu fondasi bagi berdirinya bangunan akhlak Islam. Dapat dikatakan bahwa cara yang ditempuh dalam membawakan ajaran-ajaran akhlak adalah sebagai berikut:

2) Dengan cara langsung

Nabi Muhammad saw itu sebagai muallimin al-nas al-khair yakni sebagai guru yang terbaik. Oleh karena itu, dalam menyampaikan materi ajaran-ajarannya dibidang akhlak secara langsung dapat dengan menggunakan ayat-ayat Al-Qur'an dan Al-Hadits tentang akhlak dari Nabi Muhammad saw. Dengan ayat-ayat AlQur'an dan hadis tentang akhlak cara langsung itu dapat ditempuh oleh Islam

\footnotetext{
${ }^{34}$ Mansur, Pendidikan Anak Usia Dini dalam Islam, Cet. I (Yogyakarta: Pustaka Pelajar, 2007), 257.
} 
untuk membawakan ajaran-ajaran akhlaknya. Maka wajib atas tiap-tiap makhluk mengikuti perintah Allah Swt dan RasulNya. ${ }^{35}$

3) Dengan cara tidak langsung

Dalam menyampaikan ajaran-ajaran akhlaknya, juga dapat menggunakan cara yang tidak langsung, yaitu:

a) Kisah-kisah yang mengandung nilai akhlak

Cerita atau kisah-kisah adalah sarana penerangan yang sangat digemari banyak orang, baik anak-anak maupun orang dewasa. Oleh karena itu sudah selayaknya cerita yang akan diberikan bersifat ringkas dan mempunyai tujuan yang jelas. $^{36}$

b) Kebiasaan atau latihan-latihan yang mengandung peribadatan

Untuk membina anak agar mempunyai sifat-sifat terpuji, tidaklah mungkin dengan penjelasan pengertian saja, akan tetapi perlu membiasakannya untuk melakukan yang baik yang diharapkan nanti dia akan mempunyai sifat-sifat itu, dan menjauhi sifat-sifat tercela. Kebiasaan dan latihan itulah yang membuat dia cenderung kepada melakukan yang baik dan meninggalkan yang kurang baik. Latihan-latihan keagamaan yang menyangkut ibadah seperti sembahyang, doa, membaca Al-Qur'an (atau menghafalkan ayat-ayat atau surat-surat pendek), sembahyang berjamaah, di sekolah, masjid atau langgar harus dibiasakan sejak kecil. Sehingga lama kelamaan akan tumbuh rasa senang melakukan ibadah tersebut. $^{37}$

\section{METODE PENELITIAN}

Jenis penelitian yang penulis gunakan dalam penelitian ini adalah Penelitian Kualitatif. Karena jenis penelitian yang memberikan gambaran atau uraian serta mendeskripsikan fakta empiris dengan kata-kata atau berupa pernyataan lisan tentang bagaimana peran panti asuhan dalam membentuk karakter religius anak di Panti Asuhan Almuhajirin Kota Palu ditinjau dari hukum Islam.

\footnotetext{
${ }^{35}$ Ibid, 258.

${ }^{36}$ Imran Rosadi, Kiat Mendidik Anak Masa Depan, Cet. I (Jakarta: Najla Press, 2003), 33.

${ }^{37}$ Daradjat, Ilmu, 73-75.
} 
Lokasi penelitiannya adalah Panti Asuhan Almuhajirin Kota Palu, Kelurahan Kamonji, Kecamatan Palu Barat Kota Palu. Adapun teknik pengumpulan data yang digunakan adalah teknik observasi, wawancara dan dokumentasi.

\section{HASIL PENELITIAN}

\section{A. Upaya Pengasuh dalam Membentuk Karakter Religius Anak di Panti Asuhan Almuhajirin Kota Palu}

Pendidik/pengasuh dalam proses mengimplementasikan Pembentukan karakter religius di Panti Asuhan Almuhajirin Kota Palu memegang peran yang sangat penting, peran pendidik/pengasuh tidak mungkin dapat digantikan oleh perangkat lain. Kerena pendidik/pengasuh adalah orangtua anak asuh dilingkungan tersebut. Pendidik/pengasuh memiliki tanggung jawab yang sangat besar dalam mengimplementasikan Pembentukan karakter religius sehingga anak asuh berkarakter Islami.

Tanggungjawab pendidik/pengasuh sangat besar untuk menciptakan anak asuh yang memiliki budi pekerti luhur, berprilaku baik, berpertasi, berkualitas dan berakhlak mulia. Tanggung jawab ini merupakan alat ukur kesuksesan pendidik/pengasuh dalam memberi pelajaran dan mengimplementasikan Pembentukan karakter religius.

Secara konseptual karakter merupakan serangkaian pikiran, sikap dan tingkahlaku yang berdasarkan pada nilai-nilai agama yang secara stimultan menyatu pada setiap diri manusia dalam hidupnya. Dalam konteks lembaga maka Pembentukan karakter religius merupakan nilai yang melandasi perilaku, ucapan, dan perilaku dalam keseharian yang diperaktekan oleh ketua panti dan seluruh struktur kependidikan panti dan anak asuh. Adanya budaya Pembentukan karakter religius di dalam lingkungan Panti Asuhan Almuhajirin Kota Palu merupakan suatu harapan yang diinginkan oleh semua pihak.

Panti Asuhan Almuhajirin Kota Palu, sebagai lembaga pendidikan dalam parktek kehidupan sehari-hari di lingkungan panti asuhan menurut hemat penulis telah mencerminkan adanya pembentukan karakter religius yang selalu dipraktekan, hal ini terlihat dari kesehariannya di lingkugan panti asuhan. 
Sebagaimana juga yang disampaikan oleh pengasuh Panti Asuhan Almuhajirin Kota Palu sebagai berikut:

Di dalam lingkungan panti asuhan sudah menjadi kewajiban dan prioritas utama untuk melaksanakan pembentukan karakter religius, baik dalam pembelajaran, praktek maupun kegiatan ekstrakurikuler. ${ }^{38}$

Pendidik/pengasuh merupakan komponen yang sangat menentukan dalam mengimplementasikan pembentukan karakter religius. Tanpa pendidik/pengasuh, bagaimanapun bagus dan idealnya suatu strategi pendidikan karakter, tidak akan berhasil maksimal. Peran pendidik/pengasuh dalam mengimplementasikan pembentukan karakter religius di lingkungan lembaga pendidikan tidak hanya terbatas dalam hal mengajar atau hanya menyampaikan materi pelajaran didepan anak asuh, tetapi berperan aktif dalam setiap kata, perilaku dan sikapnya menjadi profil dan contoh bagi anak asuh dalam pembentukan karakter anak asuh.

Pendidik/pengasuh dalam proses mengimplementasikan pembentukan karakter religius memegang peran yang sangat penting, peran pendidik/pengasuh, baik pada usia dini (PAUD dan TK), SD/MI, SMP/MTs maupun SMK/SMA/MA tidak mungkin dapat digantikan oleh perangkat lainnya. Selain itu pendidik/pengasuh adalah organisme yang sedang berproses dan berkembang yang sangat memerlukan bimbingan dan bantuan dari pendidik/pengasuh yang dapat dijadikan contoh dan teladan hidup.

Pendidik/pengasuh memiliki tanggung jawab yang sangat besar dalam mengimplementasikan pembentukan karakter religius sehinga anak asuh berkarakter Islami (akhlak mulia). Tanggung jawab pendidik/pengasuh sangatlah besar untuk menciptakan anak asuh memiliki budi pekerti luhur, berprilaku baik, berprestasi, berkualitas, dan berakhlak mulia. Tanggung jawab merupakan alat ukur kesuksesan pendidik/pengasuh dalam memberi bimbingan, contoh, pembelajaran dan mengimplementasikan pembentukan karakter religius di lingkungan Panti Asuhan Almuhajirin Kota Palu. Sebagaimana yang dikemukakan Iwan, Kordinator Pembinaan dan Pengasuhan, panti Asuhan:

\footnotetext{
${ }^{38}$ Abd .Larate, Kordinator Pembinaan dan Pengasuhan Panti Asuhan Almuhajirin Kota Palu, "wawancara", tanggal 20 Juni 2019.
} 
"Bahwa tugas utama pendidik/pengasuh yaitu memiliki pengetahuan, dalam mengajarkan pembentukan karakter religius harus dipraktekannya dalam kehidupan sehari-hari, sebagai model yaitu pribadi yang disiplin, cermat berpikir, mencintai karakter berbasis Islam." 39

Dari hal tersebut, jelas bahwa seorang pendidik/pengasuh selain harus memiliki pengetahuan yang diajarkan pada anak asuh, seorang pendidik/pengasuh juga berkepribadian baik, berbudi pekerti luhur, berjiwa besar dan berpengetahuan serta berwawasan global. Ukuran keberhasilan pendidik/pengasuh memiliki pengetahuan tinggi tidaklah menjadi ukuran terlaksananya pembentukan karakter religius, tetapi sejauh mana pendidik/pengasuh mampu mengembangkan kemampuan anak asuh baik kecakapan, keterampilan, pengetahuan, wawasan, dan karakter religius.

Idealnya pendidik/pengasuh harus mampu mengembangkan karakter berbasis Islam terhadap anak asuh dengan memberikan kesempatan anak asuh untuk mengembangkan kreativitasnya yang dapat dilakukan melalui kecakapan motivasi serta menciptakan iklim belajar yang aman, nyaman, dan kondusif.

Untuk mengimplementasikan pembentukan karakter religius secara efektif dan efesien ketua panti beserta pendidik perlu memiliki pengetahuan dan kemampuan dalam menyusun perencanaan dan pandangan tentang panti asuhan dan pendidikan. Ketua panti beserta pendidik harus meningkatkan sikap hubungan kepada sang khaliq, sikap kepedulian, semangat belajar, disiplin kerja, keteladanan dan hubungan manusiawi sebagai modal perwujudan karakter berbasis Islam. Selanjutnya ketua panti dituntut untuk melaksanakan fungsinya sebagai top lidersif dalam meningkatkan proses pelaksanaan pendidikan karakter berbasis Islam dengan melakukan pembinaan dan memberikan saran-saran positif kepada pendidik/pembina, serta melakukan tukar pikiran, sumbang saran dan mengikutkan dalam seminar-seminar yang berhubungan dengan pengembangan panti asuhan.

Ketua panti beserta pendidik merupakan motor pengerak penentu arah beserta tujuan panti asuhan yaitu memiliki karakter religius. Dalam penelitian ini,

\footnotetext{
${ }^{39}$ Iwan, Kordinator Pembinaan dan Pengasuhan, Panti Asuhan Almuhajirin Kota Palu, “wawancara”, tanggal 24 Juni 2019.
} 
94 | MUSA WA, Vol. 12 No.1 Juni $2020: 73-107$

peneliti telah mengidentifikasi upaya-upaya yang ditempuh oleh pendidik/pengasuh Panti Asuhan dalam rangka pembentukan karakter religius terhadap anak-anak asuh Panti Asuhan Almuhajirin Kota Palu.

Nilai-nilai religius yang ditanamkan melalui budaya religius antara lain sebagaimana diungkapkan oleh ketua yayasan: "Lembaga ini menanamkan nilai religius, antara lain uswah al-hasanah, kedisiplinan, nilai ibadah, akhlak dan sebagainya. Hal tersebut dikarenakan lembaga ini mempunyai label keagamaan. Beliau menambahkan:

Nilai keagamaan, yaitu melaksanakan shalat tepat waktu, membiasakan membaca dan menghafal Al-Qur'an, nilai pergaulan, misalnya sopan santun ketika bergaul dengan siapapun dan nilai etika, baik dalam berpakaian, kesopanan dan sebagainya.

Pernyataan yang sama juga dikemukakan habib Aljugjawi, sebagaimana perkataannya:

Nilai religius yang ditanamkan di lembaga ini antara lain uswah alhasanah, kedisiplinan, nilai ibadah, akhlak terpuji dan sebagainya. Hal tersebut dikarenakan lembaga ini merupakan lembaga keagamaan dan berada di bawah naungan yayasan juga bertanggung jawab langsung kepada masyarakat. ${ }^{41}$

Hal yang sama juga diungkapkan oleh Huriah HJ. Timi, beliau mengemukakan bahwa:

Lembaga ini menanamkan nilai religius, antara lain uswah alhasanah, kedisiplinan, ibadah, berupa shalat berjamaah, akhlak, kerukunan dan sebagainya, karena lembaga ini adalah lembaga agama. $^{42}$

Abd. Larate, juga menambahkan:

Di sini, Kami berusaha menanamkan nilai religius kepada anak didik, yang berupa uswah al-hasanah, nilai ibadah, akhlak dan sebagainya. Penanaman tersebut Kami lakukan karena pertama tuntutan lembaga dan

\footnotetext{
${ }^{40}$ Ibrahim DG. Tallesang, Ketua Panti Asuhan Almuhajirin Kota Palu, "wawancara", tanggal 26 Juni 2019.

${ }^{41}$ Habib Aljugjawi, Sekretaris, Panti Asuhan Almuhajirin Kota Palu, "wawancara", tanggal 26 Juni 2019.

${ }^{42}$ Huriah HJ. Timi, Kordinator Pembinaan dan Pengasuhan, Panti Asuhan Almuhajirin Kota Palu, "wawancara”, tanggal 26 Juni 2019.
} 
instansi yang diatasnya, kedua pertanggungjawaban moral Kami sebagai pendidik. $^{43}$

Sedangkan Iwan selaku Kordinator Pembinaan dan Pengasuhan, Panti Asuhan Almuhajirin Kota Palu, mengatakan:

Banyak sekali nilai religius yang ditanamkan di panti asuhan ini, antara lain uswah al-hasanah, kedisiplinan, nilai ibadah, akhlak dan sebagainya. Dikarenakan panggilan jiwa dan tuntutan pembelajaran. ${ }^{44}$

Lebih lanjut lagi beliau menyatakan:

Nilai yang tertanam dalam diri peserta didik cukup banyak, meliputi nilai religius, yaitu melaksanakan shalat tepat waktu, membiasakan membaca Al-Qur'an, melaksanakan puasa, shalat sunnah, nilai pergaulan, misalnya sopan santun, saling menghormati, toleransi dan nilai etika, baik dalam berpakaian, kesopanan dan sebagainya. Padahal 2 nilai yang akhir tadi sudah masuk nilai religius. ${ }^{45}$

Pembentukan karakter berguna untuk menanamkan karakter atau nilai kepada peserta didik. Berkaitan dengan hal tersebut maka ketua Panti Asuhan Almuhajirin mengemukakan nilai-nilai yang terkandung dalam pembentukan karakter adalah kejujuran, taat kepada agama, disiplin, kerjasama, toleransi, cinta ilmu, dan lain-lain. ${ }^{46}$

Sedangkan Abd. Larate mengatakan bahwa:

...dalam pendidikan karakter ini yang pertama kali diberikan kepada anak adalah nilai kepedulian Pak, kenapa ini didahulukan karena kalau nilai ini sudah ditanamkan kepada siswa, siswa akan merasa memiliki akhlak yang baik. $^{47}$

Hal ini senada dengan apa yang dikatakan oleh Habib Aljugjawi beliau mengatakan bahwa:

\footnotetext{
${ }^{43}$ Abd. Larate, Kordinator Pembinaan dan Pengasuhan, Panti Asuhan Almuhajirin Kota Palu, “wawancara”, tanggal 28 Juni 2019.

${ }^{44}$ Iwan, Kordinator Pembinaan dan Pengasuhan, Panti Asuhan Almuhajirin Kota Palu, "wawancara”, tanggal 28 Juni 2019.

${ }^{45}$ Iwan, Kordinator Pembinaan dan Pengasuhan, Panti Asuhan Almuhajirin Kota Palu, “wawancara”, tanggal 28 Juni 2019.

${ }^{46}$ Ibrahim DG. Tallesang, Ketua Panti Asuhan Almuhajirin Kota Palu, "wawancara”, tanggal 28 Juni 2019.

${ }^{47}$ Abd. Larate, Kordinator Pembinaan dan Pengasuhan, Panti Asuhan Almuhajirin Kota Palu, "wawancara”, tanggal 1 Juli 2019.
} 
96 | MUSA WA, Vol. 12 No.1 Juni $2020: 73-107$

Rasa peduli ini diberikan kepada anak supaya mereka lebih mengerti dan memahami betapa pentingnya pendidikan karakter dengan memberikan rasa peduli kepada anak, mereka akan lebih memperhatikan lagi apa yang telah mereka perbuat sehingga mereka dapat memiliki tingkah laku yang lebih baik. ${ }^{48}$

Bapak Aspir mengemukakan bahwa:

...dengan memberikan rasa peduli kepada anak, mereka akan lebih memperhatikan lagi apa yang telah mereka perbuat terhadap sesama dan lingkungannya, mereka akan lebih memikirkan lagi setiap tindakan yang mereka perbuat, seperti saling menghormati, mengucapkan salam dan sebagainya. Dari situ saja mereka sudah bisa menciptakan banyak kreasi. ${ }^{49}$

Kaitannya dengan kepedulian dan juga religius ini sesuai dengan observasi peneliti pada saat itu tidak ada lampu yang menyala di siang hari, kran kamar mandi juga tertutup, tidak ada air yang tumpah dari bak mandi. Namun, anakanak juga masih berusaha untuk tepat waktu dalam menjalankan ibadah shalat dhuhur berjamaah. Nilai tanggung jawab yang ditanamkan oleh lembaga panti asuhan ini merupakan nilai penyadaran kepada anak. Nilai ini ditanamkan mulai dari awal masuk sekolah. Seperti yang diungkapkan oleh Bapak Abd. Larate, beliau menuturkan bahwa:

Anak yang sudah diterima di panti sini, setelah kami beri materi mengenai pendidikan karakter mereka akan kami suruh melaksanakan ibadah di sekolah. Nilai tanggung jawab yang ditanamkan di sini itu nantinya diharapkan dapat dilaksanakan juga di lingkungan rumah masingmasing. ${ }^{50}$

Hal itu seperti yang yang diungkapkan oleh bapak Iwan yang mengatakan,

Dengan adanya program keagamaan sebagai pengembangan dari pendidikan agama Islam ini saya sebagai guru agama merasa lebih dimudahkan, tinggal memerintahkan dan mengajak anak- anak untuk beribadah pada waktunya. Demikian juga petugas kebersihan juga tinggal menyediakan alat-alat kebersihan, anak- anak sudah bisa membersihkan

\footnotetext{
${ }^{48}$ Habib Aljugjawi, Sekretaris, Panti Asuhan Almuhajirin Kota Palu, "wawancara", tanggal 1 Juli 2019.

${ }^{49}$ Aspir, Kepala Rumah Tangga, Panti Asuhan Almuhajirin Kota Palu, “wawancara”, tanggal 1 Juli 2019.

${ }^{50}$ Abd. Larate, Kordinator Pembinaan dan Pengasuhan, Panti Asuhan Almuhajirin Kota Palu, "wawancara”, tanggal 3 Juli 2019.
} 
sendiri lingkungan panti asuhan ini. Petugas kebersihan hanya membantu anak-anak dan memberi arahan kepada anak. ${ }^{51}$

Begitu juga yang diungkapkan oleh ibu Huriah HJ. Timi bahwa:

Menurut saya, setelah mengupayakan penanaman nilai hasilnya bisa dilihat dari semakin hari anak-anak semakin mempunyai rasa tanggung jawab dan kepedulian terhadap lingkungan, meskipun ada beberapa anak yang masih perlu ditanamkan lagi nilai-nilai tanggung jawab karena tidak semua siswa/anak mempunyai kesadaran yang sama terhadap ibadahnya. ${ }^{52}$

Nilai tanggung jawab ini diberikan oleh panti asuhan kepada anak didik agar anak-anak bisa mengaplikasikannya di lingkungan luar panti asuhan. Dari nilai tanggung jawab yang telah dilaksanakan anak di panti asuhan akan membiasakan anak berperilaku yang baik yang memperhatikan dirinya sendiri terutama ibadahnya. Anak asuh yang mengerti tanggung jawab akan lebih mempertimbangkan lagi setiap tindakan yang mereka perbuat karena dampak dari yang mereka perbuat akan mereka terima akibatnya. Berdasarkan uraian di atas, dapat dikemukakan bahwa nilai-nilai religius yang ditanamkan di panti asuhan terdiri dari kejujuran, taat kepada agama, disiplin, kerjasama, toleransi, cinta ilmu, dan tanggung jawab.

Jadi nilai-nilai religius yang ditanamkan di panti asuhan antara lain: nilai ibadah, nilai pergaulan, nilai akhlak, nilai kedisiplinan, dan sebagainya. Nilainilai tersebut ditanamkan karena berbagai alasan, yaitu tanggung jawab moral pendidik, dan tanggung jawab lembaga terhadap masyarakat.

\footnotetext{
${ }^{51}$ Iwan, Kordinator Pembinaan dan Pengasuhan, Panti Asuhan Almuhajirin Kota Palu, “wawancara”, tanggal 3 Juli 2019.

${ }^{52}$ Huriah HJ. Timi, Kordinator Pembinaan dan Pengasuhan, Panti Asuhan Almuhajirin Kota Palu, “wawancara”, tanggal 3 Juli 2019.
} 
98 | MUSA WA, Vol. 12 No.1 Juni 2020 : 73-107

\section{B. Tinjauan Hukum Islam terhadap Peran Pengasuh Panti Asuhan dalam Membentuk Karakter Religius Anak di Panti Asuhan Almuhajirin Kota Palu}

1. Peran pengasuh (pendidik) Panti Asuhan dalam membentuk karakter religius anak di Panti Asuhan Almuhajirin Kota Palu dalam perspektif Islam.

Tujuan Panti Asuhan adalah menjadikan anak mampu melaksanakan perintah agama, mengantarkan anak mulia dan mencapai kemandirian dalam hidup dibidang ilmu dan ekonomi, menjadikan anak mampu menghadapi masalah secara arif dan bijaksana dan memberikan pelayanan kesejahteraan kepada anakanak yatim dan miskin dengan memenuhi kebutuhan fisik mental dan sosial agar nantinya mereka mampu hidup layak dan hidup mandiri di tengah-tengah masyarakat. Pelayanan dan pemenuhan kebutuhan anak di panti asuhan dimaksudkan agar anak dapat belajar dan berusaha mandiri serta tidak hanya menggantungkan diri tehadap orang lain setelah keluar dari panti asuhan. $^{53}$

Berdasarkan bebeapa pendapat diatas mengenai peran pengasuh panti asuhan anak yatim dapat diaambil suatu kesimpulan bahwa memberikan pelayanan berdasarkan pada profesi pekerjaan sosial kepada anak-anak yang tidak memiliki ayah atau ibu (yatim) atau keduanya (yatim-piatu) sebagai pengganti orang tua dengan cara mengasihi dan menyayangi serta membantu dan membimbing (merawat, menjaga, dan mendidik) mereka kearah perkembangan kepribadian yang baik, berakhlakul karimah serta kemampuan kemandirian, sehingga mereka menjadi anggota masyarakat yang hidup layak dan penuh tanggung jawab baik terhadap dirinya.

Adapun keutamaan lain jika kita mengasuh anak yatim secara tulus dan ikhlas di antaranya sebagai berikut:

a. Menjauhkan kita dari sifat kikir.

Kikir adalah salah satu penyakit yang mendatangi manusia agar terlepas dari sifat yang dermawan, solidaritas, dan suka memberikan pertolongan. Jika kita melakukan sedekah atau menyantuni anak yatim, meskipun dengan sedikit harta

\footnotetext{
${ }^{53}$ https://www.binaaku.web.id/2013/03/peran pengasuh pantiasuahn-dalam-perspektifislam.html, Diakses 7 Agustus 2019.
} 
yang kita miliki, sifat kikir ini akan menghalanginya sehingga dia membatalkan niatnya untuk bersedekah atau berinfak. ${ }^{54}$ Karena itu kita seringkali menjumpai ayat-ayat yang menjelaskan tentang infak dan sedekah selalu disertai dengan manfaat yang didapatkan dari perbuatan itu, seperti pada firman Allah SWT. yang terdapat dalam QS. Al-Lail [92]: 18 Berikut ini:

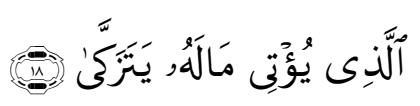

Terjemahnya:

"Yang Menafkahkan Hartanya (Dijalan Allah) Untuk Membersihkannya".

Ayat tersebut menjelaskan bahwa dengan berinfak, jiwa seseorang akan bersih, karena kikir bukan merupakan akhlak seorang mukmin.

b. Menanamkan sifat istiqamah.

Amalan yang dicintai Allah adalah amalan yang sedikit, tetapi kontinu. Mengasuh seorang anak yatim dengan baik di rumah kita adalah salah satu sarana untuk menanamkan sifat istiqamah pada kita dan keluarga kita. Sifat istiqamah ini juga merupakan sikap yang terpenting setelah kita beriman kepada Allah. Jika kita sabar dan istiqamah dalam mengasuh atau menyantuni anak yatim dengan segala tingkah laku mereka, Allah menjanjikan keberuntungan besar bagi yang melaksanakannya yakni surga. ${ }^{55}$

Orang-orang yang menyantuni anak yatim diberikan kemuliaan yang luar biasa, dan sebaiknya orang-orang yang mengabaikan hak-hak mereka justru mendapatkan ancaman dari Allah SWT. Allah memperingatkan manusia agar senantiasa menyantuni anak yatim sebagaimana firman-Nya dalam QS. Al-Fajr [89]: 17 yaitu:

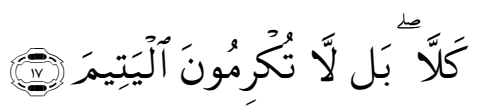

Terjemahnya:

"sekali-kali tidak (demikian), sebenarnya kamu tidak memuliakan anak yatim".

\footnotetext{
${ }^{54}$ Zakiyatul Hayat, Skripsi: Pemeliharaan Anak Yatim Dalam Persfektif Alquran (Banjarmasin: IAIN Antasari, 2002), 16.

${ }^{55}$ Ibid.,
} 
Menyantuni anak yatim dalam Islam merupakan salah satu bentuk pembuktian ketaatan di dalam menganut agama Islam yang berarti tunduk dan patuh. Orang-orang yang mengabaikan anak yatim bahkan bersikap kasar dengan menghardik mereka dianggap sebagai orang yang berdusta dalam beragama. Artinya amalan apapun yang mereka lakukan di dalam agama dianggap sebagai kedustaan yang tentu saja hal ini akan menyebabkan sisa-sianya amal dan perbuatan yang dilakukan. Kewajiban kita untuk mengasuh anak yatim, karena mereka adalah saudara kita sesama muslim, baik kerabat maupun orang yang tidak ada hubungan kekerabatan dengan kita.

Tujuan untuk mengasuh anak yatim piatu yaitu untuk menciptakan sumber daya manusia yang bermutu dan berkualitas. Islam sendiri mengajarkan bahwa setiap muslim hendaknya memiliki kualitas diri yang baik. Karena apabila setiap muslim mampu menjadi manusia yang baik, dia akan mampu menjadi pengemban peradaban manusia yang seimbang. ${ }^{56}$ Tujuan merupakan faktor yang penting untuk menentukan jenis pola asuh. Jenis pola asuh yang baik yaitu pola asuh yang dapat digunakan untuk mencapai tujuan yang diinginkan. Salah satu kegiatan yang digunakan untuk membentuk karakter religius adalah kegiatan shalat berjamaah.

Kegiatan shalat lima waktu secara berjamaah hukumnya wajib untuk menanamkan karakter religius kepada anak-anak bahkan anak-anak diajari untuk menjadi imam dan mengimami shalat dhuhur. Maka anak-anak panti asuhan alIkhlas juga ditanamkan karakter kepemimpinan dengan cara mengimami shalat dhuhur teman-temannya.

Peran pengasuh panti asuhan dalam membentuk karakter religius santri dengan mendisiplinkan shalat berjamaah dan melatih anak menjadi pemimpin jamaah bagi kalangannya sendiri. Ibadah merupakan bahasa Indonesia yang berasal dari bahasa Arab, yaitu dari masdar 'abada yang berarti penyembahan. Sedangkan secara istilah berarti khidmat kepada Tuhan, taat mengerjakan

\footnotetext{
${ }^{56}$ Ibnu Musthofa, Keluarga Islam Menyongsog Abad 21, Cet. I (Bandung: Mizan, 1993),
} 128. 
perintahnya dan menjauhi larangannya. ${ }^{57}$ Jadi ibadah adalah ketaatan manusia kepada Tuhan yang diimplementasikan dalam kegiatan sehari-hari misalnya sholat, puasa, zakat, dan lain sebagainya.

Nilai ibadah perlu ditanamkan kepada diri seorang anak didik, agar anak didik menyadari pentingnya beribadah kepada Allah. bahkan penanaman nilai ibadah tersebut hendaknya dilakukan ketika anak masih kecil dan berumur 7 tahun, yaitu ketika terdapat perintah kepada anak untuk menjalankan shalat. Dalam ayat yang menyatakan tentang shalat misalnya redaksi ayat tersebut memakai lafadh aqim bukan if'al. Hal itu menunjukkan bahwa perintah mendirikan shalat mempunyai nilai-nilai edukatif yang sangat mendalam, karena shalat itu tidak hanya dikerjakan sekali atau dua kali saja, tetapi seumur hidup selama hayat masih dikandung badan. ${ }^{58}$ Penggunaan kata aqim tersebut juga menunjukkan bahwa shalat tidak hanya dilakukan, tetapi nilai shalat wajib diimplementasikan dalam kehidupan sehari-hari, misalnya kedisiplinan, ketaatan kepada Tuhannya, dan lain sebagainya. Menurut Wahbah Zuhaily, penegakan nilai-nilai shalat dalam kehidupan merupakan manifestasi dari ketaatan kepada Allah. Shalat merupakan komunikasi hamba dan khaliknya, semakin kuat komunikasi tersebut, semakin kukuh keimanannnya

Sebagai seorang pendidik, guru tidak boleh lepas dari tanggung jawab begitu saja, namun sebagai seorang pendidik hendaknya senantiasa mengawasi anak didiknya dalam melakukan ibadah, karena ibadah tidak hanya ibadah kepada Allah atau ibadah mahdlah saja, namun juga mencakup ibadah terhadap sesama atau ghairu mahdlah. Ibadah di sini tidak hanya terbatas pada menunaikan shalat, puasa,mengeluarkan zakat dan beribadah haji serta mengucapkan syahadat tauhid dan syahadat Rasul, tetapi juga mencakup segala amal, perasaan manusia, selama manusia itu dihadapkan karena Allah Swt. Ibadah adalah jalan hidup yang mencakup seluruh aspek kehidupan serta segala yang dilakukan manusia dalam mengabdikan diri kepada Allah Swt.

\footnotetext{
${ }^{57}$ Badudu Js, Kamus Umum Bahasa Indonesia, Cet. I (Jakarta: Pustak Sinar harapan, 1996), 524.

${ }^{58}$ Anisatul Mufarakah, "Pendidikan Dalam Perspektif Luqman al-Hakim: Kajian Atas QS: Luqman ayat 12-19", dalam Ta'allum Jurnal Pendidikan Islam Vol.18.No.01, juni 2008, 8.
} 
102 | MUSA WA, Vol. 12 No.1 Juni 2020 : 73-107

Tanpa ibadah, maka manusia tidak dapat dikatakan sebagai manusia secara utuh, akan tetapi lebih identik dengan makhluk yang derajatnya setara dengan binatang. Maka dari itu, agar menjadi manusia yang sempurna dalam pendidikan formal diinkulnasikan dan diinternalisasikan nilai-nilai ibadah. Sebagaimana yang dikisahkan oleh Allah dalam firmannya QS. Al-Kahfi [18] 66-70.

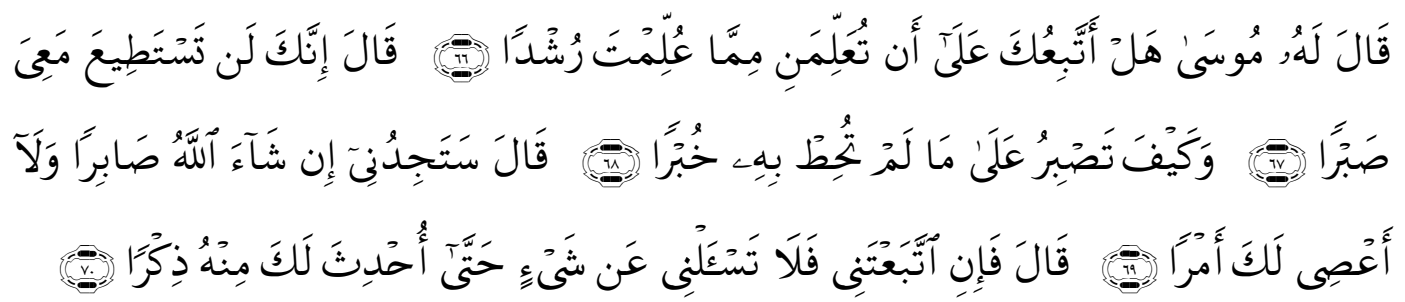

Terjemahnya:

Musa berkata kepada Khidhr: "Bolehkah aku mengikutimu supaya kamu mengajarkan kepadaku ilmu yang benar di antara ilmu-ilmu yang telah diajarkan kepadamu?"Dia menjawab: "Sesungguhnya kamu sekali-kali tidak akan sanggup sabar bersama aku. dan bagaimana kamu dapat sabar atas sesuatu, yang kamu belum mempunyai pengetahuan yang cukup tentang hal itu?" Musa berkata: "Insya Allah kamu akan mendapati aku sebagai orang yang sabar, dan aku tidak akan menentangmu dalam sesuatu urusanpun". Dia berkata: "Jika kamu mengikutiku, Maka janganlah kamu menanyakan kepadaku tentang sesuatu apapun, sampai aku sendiri menerangkannya kepadamu". 59

Adapun tafsiran ayat ini yaitu Dalam pertemuan kedua tokoh itu musa berkata kepadanya, yakni kepada hamba Allah yang memperoleh ilmu khusus itu, "Bolehkah aku mengikutimu secara bersungguh-sungguh supaya engkau mengajarkan kepadaku sebagian dari apa, yakni ilmu-ilmu yang telah di ajarkan Allah kepadamu untuk menjadi petunjuk bagiku menuju kebenaran?”. Dia menjawab, "Sesungguhnya engkau hai musa sekali-kali tidak akan sanggup sabar bersamaku. Yakni peristiwa-peristiwa yang engkau akan alami bersamaku, akan membuatmu tidak sabar. Dan, yakni padahal bagaimana engkau dapat sabar atas sesuatu, yang engkau belum jangkau secara menyeluruh hakikat beritanya?"

\footnotetext{
${ }^{59}$ Departemen Agama RI, Al-Qur'an, 439.
} 
Engkau tidak memiliki pengetahuan bathiniah yang cukup tentang apa yang akan engkau lihat dan alami bersamaku itu. ${ }^{60}$

Ucapan hamba Allah ini, memberi isyarat bahwa seorang pendidik hendaknya menuntun anaknya menuntun anak didiknya dan memberi tahu kesulitan-kesulitan yang akan dihadapi dalam menuntut ilmu, bahkan mengarahkannya untuk tidak mempelajari sesuatu jika sang pendidik mengetahui bahwa potensi anak didiknya tidak sesuai dengan bidang ilmu yang akan dipelajarinya. ${ }^{61}$

Mendengar komentar sebagaimana terbaca pada ayat yang lalu dia, Nabi Musa AS terkata kepada hamba yang shaleh itu "engkau Insya' Allah akan mendapati aku sebagai seorang penyabar yang insya' Allah mampu menghadapi ujian dan cobaan, dan kau tidak akan menentangmu dalam sesuatu perintah yang engkau perintahkan atau urusan apapun".

"Dia berkata, jika engkau mengikutiku secara bersungguh-sungguh, maka seandainya engkau melihat hal-hal yang tidak sejalan dengan pendapatmu atau bertentangan dengan apa yang engkau ajarkan, maka janganlah engkau menanyakan kepadaku tentang sesuatu apapun, yang aku kerjakan atau ku ucapakan sampai bila tiba waktunya nanti aku sendiri menerangkannya kepadamu". Demikian hamba yang shaleh itu menetapkan syarat ke ikut sertaaan Nabi Musa AS.

Ucapan Isya' Allah itu disamping merupakan adab yang di ajarkan semua agama dalam menghadapi sesuatu di masa depan, ia juga mengandung makna permohonan kiranya memperoleh bantuan Allah SWT dalam menghadapi sesuatu. Apalagi dalam belajar, khususnya dalam mempelajari dan mengamalkan hal-hal yang bersifat batiniah/tasawuf. Ini lebih penting lagi bagi seseorang yang telah memiliki pengetahuan, karena boleh jadi pengetahuan, karena boleh jadi pengetahuan yang dimilikinya tidak sejalan dengan sikap atau apa yang di ajarkan sang guru. ${ }^{62}$

\footnotetext{
${ }^{60}$ M. Quraish Shihab, Tafsir Al mishbah (Pesan, Kesan dan keserasian Al-Qur'an) volume , Cet. II (Jakarta: Lentera Hati, 2002), 97.

${ }^{61}$ Ibid, 99.

${ }^{62}$ Ibid, 100-101.
} 
Kisah ini antara Nabi Musa dan Khidir bisa menjadi pedoman dalam adab dan sopan santun seorang murid terhadap gurunya dan semangat untuk mencari ilmu. ${ }^{63}$ Selanjutnya beberapa ayat ini juga mengsiyaratkan bahwa seorang guru harus bisa menghormati muridnya dengan berbaik hati. Selain itu, seorang guru harus bersikap bijaksana dengan memberikan kesimpulan atas pengajaran yang diberikan kepada muridnya, sehingga anak didiknya akan mengetahui maksud materi pengajaran.

Menurut Ahmad Tafsir Tugas dan tanggung jawab seorang guru sebagai pendidik adalah mendidik sekaligus mengajar, yaitu membantu peserta didik untuk mencapai kedewasaan. Dalam proses pembelajaran tugas utama guru selain sebagai pengajar juga sebagai pembimbing. Guru hendaknya memahami semua aspek pribadi peserta didik baik fisik maupun psikis dan mengenal, memahami tingkat perkembangan peserta didiknya yang meliputi kebutuhan, pribadi, kecakapan, kesehatan mentalnya, dan lain sebagainya. Perlakuan bijaksana akan muncul apabila guru benar-benar memahami seluruh aspek kepribadian peserta didiknya. ${ }^{64}$

Untuk membentuk pribadi baik siswa yang memiliki kemampuan akademik dan religius. Penanaman nilai-nilai tersebut sangatlah urgen. Bahkan tidak hanya siswa, guru dan karyawan juga perlu penanaman nilai- nilai ibadah, baik yang terlibat langsung maupun tidak langsung. Selain dengan shalat berjamaah, pembentukan karakter religius juga dilakukan dengan pembiasaan tadarrus. Anak-anak dibiasakan untuk tadarus supaya anak terbiasa untuk membaca al-Qur'an dan juga anak-anak diharapkan mampu lancar membaca alQur'an. Peran pengasuh yaitu menjadi pengawas dan pengajar anak yang melakukan tadarrus. Anak-anak harus diawasi dan diberi peraturan yang cukup supaya anak disiplin dalam melakukan tadarrus.

\footnotetext{
${ }^{63}$ Kementrian Agama Republik Indonesia, Alqur'an dan tafsirnya jilid 5 (Jakarta: Widya Cahaya, 2011), 642.

${ }^{64}$ Ahmad Tafsir, Metodologi Pengajaran Agama Islam, Cet. I (Bandung: Remaja Rosdakarya, 2004), 78.
} 


\section{KESIMPULAN}

Upaya pengasuh dalam dalam membentuk karakter religius anak di Panti Asuhan Almuhajirin Kota Palu sangat didukung dengan situasi dan kondisi Panti Asuhan Almuhajirin Kota Palu. Dengan tinggalnya para anak asuh di asrama, pembentukan karakter berbasis religius dapat dilakukan secara optimal. Nilai-nilai karakter berbasis religius yang dikembangkan meliputi religius, disiplin, gemar membaca, peduli lingkungan, bertanggung jawab dan kejujuran. Implementasi pembentukan karakter berbasis religius bertujuan untuk membuat seseorang menjadi insan kamil, Bentuk-bentuk implementasi pendidikan karakter terwujud dalam penanaman keimanan, pemberian bimbingan, memberikan teladan/contoh yang baik,penegakkanaturan, pemberian nasihat, motivasi serta mengadakan pengawasan

Tinjauan dari hukum Islam terhadap peran pengasuh yaitu meliputi mendidik, mengajar dan melatih. Mendidik berarti meneruskan dan mengembangkan nilai-nilai hidup/kepribadian. Mengajar berarti meneruskan dan mengembangkan ilmu pengetahuan dan teknologi. Sedangkan melatih berarti mengembangkan keterampilan-keterampilan pada anak asuh berdasarkan QS. AlKahfi [18] 66-70. Sedangakan pembentukan karakter dalam Islam sama dengan pendidikan akhlak dan juga merupakan pensucian jiwa dan karakter manusia menjadi manusia yang bertakwa bedasarkan Al-Qur'an dan Hadits.

\section{DAFTAR PUSTAKA}

Arifin. Filsafat Pendidikan Islam, Cet. V. Jakarta: Bumi Aksara, 2000

Asri, Budiningsih. Pembelajaran Moral, Cet. I. Jakarta : Rineka Cipta, 2004

Badudu , Js. Kamus Umum Bahasa Indonesia, Cet. I. Jakarta: Pustak Sinar harapan, 1996

Daradjat, Zakiah. Ilmu Jiwa Agama, Cet. XXII. Jakarta: Bulan Bintang, 2003

Departemen Agama RI. Al-Qur'an dan Terjemahnya. Jakarta: Toha Putra, 2008 
106 | MUSA WA, Vol. 12 No.1 Juni 2020 : 73-107

facebook.com/topic.php?uid=122204804480235\&topic=157)http://id-id, Diakses 7 Agustus 2019.

Hadi, Sutrisno. Metodologi Penelitian, Cet. I. Yogyakarta: Andi Ooffset, 1989

Hamka. Tafsir al-Azhar, Juz 4, Cet. II. Jakarta: Pustaka Panjimas, 2004

Hayat, Zakiyatul. Skripsi: Pemeliharaan Anak Yatim Dalam Persfektif Alquran. Banjarmasin: IAIN Antasari, 2002

http://bukhariumar.stainbatusangkar.ac.id/?p=20, Diakses 7 Agustus 2019.

http://riwayat.wordpress.com/2008/01/25/metode-mendidik-akhlak-anak/, Diakses 7 Agustus 2019.

Kadir, Sardjan. Perencanaan Pendidikan informal, Cet. I. Jakarta: Ciputat Press, 2002.

Kahar, M. Iksan. Pendidikan Karakter pada Anak Usia Dini dalam Perspektif Islam, Musawa: Journal For Gender Studies, Vol 11(01) 2019.

Kementrian Agama Republik Indonesia, Alqur'an dan tafsirnya jilid 5. Jakarta: Widya Cahaya, 2011

Khan, Yahya. Pendidikan Karakter Berbasis Potensi Diri. Mendongkrak Kualitas Pendidikan. Cet. II. Bandung: Pelangi Publishing, 2010

Koesoema, A Donie. Pendidikan Karakter, Cet. I. Jakarta: Grasindo, 2007

Lickona, Thomas. Terjemahan; education of carakter, Bandung: alfabeta,1991.(https://www.scribd.com/07/ringkasan+buku+karakter+lick ona/htm), Diakses 12 Maret 2019

Mansur. Pendidikan Anak Usia Dini dalam Islam, Cet. I. Yogyakarta: Pustaka Pelajar, 2007

Moleong, Lexi J. Metodologi Penelitian Kualitas, Cet. VI. Bandung: Remaja Rosda Karya, 2008

Muchtar, Heri Jauhari. Fikih Pendidikan, Cet. I. Bandung, Remaja Rosdakarya, 2005

Mufarakah, Anisatul. "Pendidikan Dalam Perspektif Luqman al-Hakim: Kajian Atas QS: Luqman ayat 12-19", dalam Ta'allum Jurnal Pendidikan Islam Vol.18.No.01, juni 2008, 8. 
Musfidah, Tadkirotun. Pembinaan karakter di SM, Cet. III. Jakarta: Direktorat PSMP, 2008

Musthofa, Ibnu. Keluarga Islam Menyongsog Abad 21, Cet. I. Bandung: Mizan, 1993

Nasir, Sahilun A. Tinjauan Akhlak, Cet. I. Surabaya: Al-Ikhlas, 1991

Qadir Ahmad, Muhammad abdul. Metodologi Pengajara Pendidikan Agama Islam, Cet. I. Jakarta: Direktorat Jendral Pembinaan Kelembagaan Agama Islam, 1985.

Raharjo, F.X.Supriyono. Pembentukan Karakter dan Pengembanagan Kompetensi Siswa, Cet. I. Bandung: Tiga Serangkai, 2006

Rosadi, Imran. Kiat Mendidik Anak Masa Depan, Cet. I. Jakarta: Najla Press, 2003

S, Sudjana. Pendidikan informal Wawasan Sejarah Perkembangan Karakter, Cet. I. Jakarta: Prenada Media, 2007

Shihab, M. Quraish. Tafsir Al mishbah (Pesan, Kesan dan keserasian Al-Qur'an) volume , Cet. II. Jakarta: Lentera Hati, 2002

Sudewo. Penddidikan Karakter, Cet. I. Bandung: Rafika Publiset, 2008

Sukandarrumidi. Metodologi Penelitian. Yogyakarta: Gajah Mada University Press, 2004

Syaputra, Thoyib Sah . Aqidah Akhlak Madrasah Tsanawiah Kelas Satu, Cet. I. Semarang : Toha Putra, 1994

Umary, Barmawie. Materi Akhlak, Cet. I. Solo: CV. Ramadhani, 1991

Undang Undang No. 23 tahun 2002 tentang Perlindungan Anak pasal 55 dan pasal 56.

Wardani. Pendidikan Karakter Kajian Konseptual dan Kemungkinan Implementasi Cet. I. Jakarta: Diadit Media, 2008

Yunus, Mahmud. Metodik Khusus Pendidikan Agama, Cet. I. Jakarta: Hidakarya Agung, 1983

Zuchdi, Darmiyati. Humanisasi Pendidikan, Cet. I. Jakarta: Bumi Aksara, 2009. 